\title{
THERMAL-HYDRAULIC ANALYSIS OF SMR WITH NATURALLY CIRCULATING PRIMARY SYSTEM DURING LOSS OF FEED WATER ACCIDENT
}

\author{
Susyadi \\ Center for Nuclear Reactor Technology \& Safety - BATAN \\ Kawasan PUSPIPTEK gedung 80, Setu, Tangerang Selatan, 15310 \\ Email: susyadi@batan.go.id, telp: 021-7560912,fax: 021-7560913 \\ Diterima editor: 21 April 2016 \\ Diperbaiki: 26 Agustus 2016 \\ Disetujui untuk publikasi: 29 Agustus 2016
}

\begin{abstract}
THERMAL-HYDRAULIC ANALYSIS OF SMR WITH NATURALLY CIRCULATING PRIMARY SYSTEM DURING LOSS OF FEED WATER ACCIDENT. Small Modular Reactors (SMRs) have several advantages over conventional large reactors. With integral and simplified design, application of natural laws for safety system, and lower capital cost this reactor is very suitable to be deployed in Indonesia. One of SMR designs being developed implements natural driving force for its primary cooling system. With such innovative approach, it is important to understand safety implication of the design for all operating circumstances. One of conditions need to be investigated is the loss of feedwater (LoFW) accident. In this study, thermal-hydraulic performance of the SMR with naturally circulating primary system during LoFW accident is analysed. The purpose is to investigate the characteristics of flow in primary system during the accident and to clarify whether the naturally circulating coolant is adequately capable to transfer the heat from core in order to maintain safe condition under considered scenario. The method used is by representing the reactor system into RELAP5 code generic models and performing numerical simulation. Calculation result shows that following the initiating event and reactor trip, primary system flow becomes significantly fluctuated and coolant temperature decreases gradually, while in secondary side steam quality descends into saturated. The primary flow slows down from $\sim 711 \mathrm{~kg} / \mathrm{s}$ to $\sim 263 \mathrm{~kg} / \mathrm{s}$ and starts to increase up again at $\mathrm{t}=\sim 46$ seconds. At the slowest point, fuel centerline and coolant temperatures were $\sim 565 \mathrm{~K}$ and $\sim 554 \mathrm{~K}$, showing that temperatures of the fuel and coolant are still below its design limit and saturation point, respectively. This fact reveals that throughout transient the two main thermal hydraulic parameters stay in acceptable values so it could be concluded that under LoFW accident the SMR with naturally circulating primary system is in safe condition.
\end{abstract}

Keywords: SMR, loss of feed water, natural circulation, reactor safety, RELAP5

\section{ABSTRAK \\ ANALISIS THERMAL-HIDROLIK SMR BERSISTEM PRIMER SIRKULASI ALAM SAAT}

KECELAKAAN KEHILANGAN AIR UMPAN. Reaktor daya kecil modular (SMR) memiliki beberapa keunggulan dibanding reaktor daya besar konvensional. Dengan disain yang lebih sederhana dan terintegrasi, penerapan hukum alamiah untuk sistem keselamatannya dan biaya modal yang rendah, reaktor ini sangat cocok untuk dibangun di Indonesia. Salah satunya disain SMR yang sedang dikembangkan menerapkan gaya penggerak alami untuk sistim pendingin primernya. Dengan disain seperti itu, adalah sangat penting untuk memahami implikasinya terhadap aspek keselamatan pada seluruh kondisi operasi. Salah satu yang perlu diinvestigasi adalah kecelakaan kehilangan air umpan (LoFW). Pada studi ini, dilakukan analisis kinerja thermal hidrolik SMR yang menggunakan sistim pendinginan primer sirkulasi alam saat kecelakaan LoFW. Tujuannya adalah untuk menginvestigasi karakteristik aliran sistem primer saat kecelakaan LoFW dan untuk memastikan apakah aliran sirkulasi alam cukup untuk memindahkan panas dari teras guna menjaga kondisi tetap aman selama kecelakaan tersebut. Metoda yang digunakan adalah dengan merepresentasikan sistem reaktor ke dalam modelmodel generik program RELAP5 dan melakukan simulasi numerik. Hasil perhitungan menunjukkan bahwa setelah kejadian pemicu dan trip reaktor, pada sisi primer laju alirnya berfluktuasi secara signifikan dan temperatur pendinginnya menurun secara bertahap sedangkan pada sisi sekunder kondisi uap berubah menjadi uap jenuh. Laju alir turun dari $\sim 711 \mathrm{~kg} /$ detik menjadi $\sim 263 \mathrm{~kg} /$ detik sebelum kembali naik lagi pada $t=\sim 46$ detik. Saat laju alir di titik terendah, temperatur pusat bahan bakar dan fluida pendingin adalah sekitar $\sim 565 \mathrm{~K}$ dan $\sim 554 \mathrm{~K}$, yang menujukkan bahwa temperatur bahan bakar masih jauh di bawah batas disain dan temperatur fluidanya juga berada di bawah titik saturasi. Keadaan ini menunjukkan bahwa saat transien kedua parameter utama termohidrolik reaktor tetap dalam kondisi yang dapat diterima sehingga dapat disimpulkan bahwa saat kecelakaan kehilangan air umpan, SMR dengan sistim primer sirkulasi alam tetap dalam kondisi aman.

Kata kunci: SMR, kehilangan air umpan, sirkulasi alamiah, keselamatan reaktor, RELAP5 


\section{INTRODUCTION}

Small Modular Reactors (SMRs) have several advantages over conventional large reactors. The highly regarded points comprise of: (1) more compact design, (2) improved safety level, (3) more reliable system and (4) economically more competitive [1]. Essentially, these are achieved through integral design - where all steam supply system components are located in single vessel; application of natural laws for safety system - such as gravity based passive system for emergency core cooling and residual heat removal; design simplification - through reduction of active components; and lower capital cost - which makes it more affordable for developing countries or owners with limited budget. For Indonesia, this reactor type is suitable to be deployed in eastern and middle parts of the country where electrical grid capacity is still low [2-7]. Therefore, it is very important to understand the design characteristic, work mechanism and safety aspects of this reactor.

Nowadays, numerous SMR designs are being developed in different level of extensiveness [8-12]. Their stages vary from under conceptual design, design certification process to under construction. Among others, these reactors are: Westinghouse SMR, mPower, NuScale (USA) [1315], SMART (South Korea)[16], KLT-40S, RITM200 (Rusia)[15, 17], ACP100 (China)[18], CAREM-25 (Argentine) [19], etc. Mostly, each design has a specific characteristic that shows technological advancement implemented in the system. One of them is an integral PWR which implements natural driving force for its primary system, or in other words, the reactor does not use pumps to circulate the primary coolant [15]. With such design, characteristics of the primary flow would be different from conventional PWRs (having primary pumps), either for normal operation, transient or accident conditions as the flow becomes more sensitive against parameter changes in the reactor system. Consequently, it is important to understand safety implication of this innovative design during all operating circumstances. One of conditions need to be investigated is the loss of feed-water (LoFW) accident. For conventional PWRs, works on typical LoFW accident have been extensively conducted and published as this reactor type has been constructed since the first generation of NPPs and its analysis result was generally included in the document of safety analysis report (SAR) for licensing purpose. More recent studies of LoFW transient in conventional reactor were performed by Bánáti, J et. Al. [20] and Ekariansyah et.at. [21]. The former focused on the capabilities of the model used to reproduce the system response on a large disturbance originating from the secondary side and to test the performance of the control system and the trip logic of the Ringhals-3 reactor. The later investigated primary system transient and the capability of passive residual heat removal (PRHR) heat exchanger in the AP1000 reactor using RELAP5. However, for the case of SMR with naturally circulating primary system, works and publications on the LoFW analysis is quite infrequent. A research that closely relates to this was conducted by Chung Y.J which explored the event of LoFW on integral test facility of MASLWR (a test facility which reperesents SMR with naturally circulating primary system having scale of 1:3 for length and 1:254 for volume [22]) in order to check the validity of TASS/SMR code [23]. With the same facility, other researchers investigated similar transient using RELAP5[24] and MARS-KS [25] codes.

In this study, the thermal-hydraulic performance of SMR with naturally circulating primary system during LoFW accident is analysed. The purpose is to investigate the characteristics of the flow in primary system during LoFW accident and to clarify whether the naturally circulating flow is adequately capable to remove the heat from core in order to maintain safe condition during the considered scenario. The method used is by representing the reactor system into the RELAP5 code generic models and performing numerical simulation. As the SMR being investigated is still under design stage and there is possibility that some of the reactor's parameters and geometries are changed in the future, hence the result of this study is more intended for qualitative understanding of the reactor behaviours occurring in the accident rather than for preciseness of the quantitative output. 


\section{DESCRIPTION OF SMR WITH NATURALLY CIRCULATING SYSTEM}

Schematic diagram, picture and basic parameters of reactor system being the focus of this research are presented in Figure 1 and Table 1. The reactor is an SMR employing natural circulation flow in its primary system that technologically is being developed by NuScale Power Inc. and planned to be under US-NRC design certification process by the end of 2016. Thermal power of the reactor is $160 \mathrm{MWt}$ and can produce gross electricity about $50 \mathrm{MWe}$. The whole steam supply system is enclosed in a single vessel which is approximately $17.7 \mathrm{~m}$ in height and 2.7 $\mathrm{m}$ in diameter. This vessel is encapsulated in $23.2 \mathrm{~m}$ tall and $4.6 \mathrm{~m}$ in diameter [26] of steel containment which is then termed as a module. The air inside containment is eliminated so the pressure nearly vacuum. In deployment site, the module is immersed in large water-filled pool built below grade inside reactor building. Several power modules (up to 12 modules) can be co-located in the same pool. A single NuScale module can produce roughly $245000 \mathrm{~kg} / \mathrm{hr}$ steam with an outlet temperature is approximately $300{ }^{\circ} \mathrm{C}$ [27].
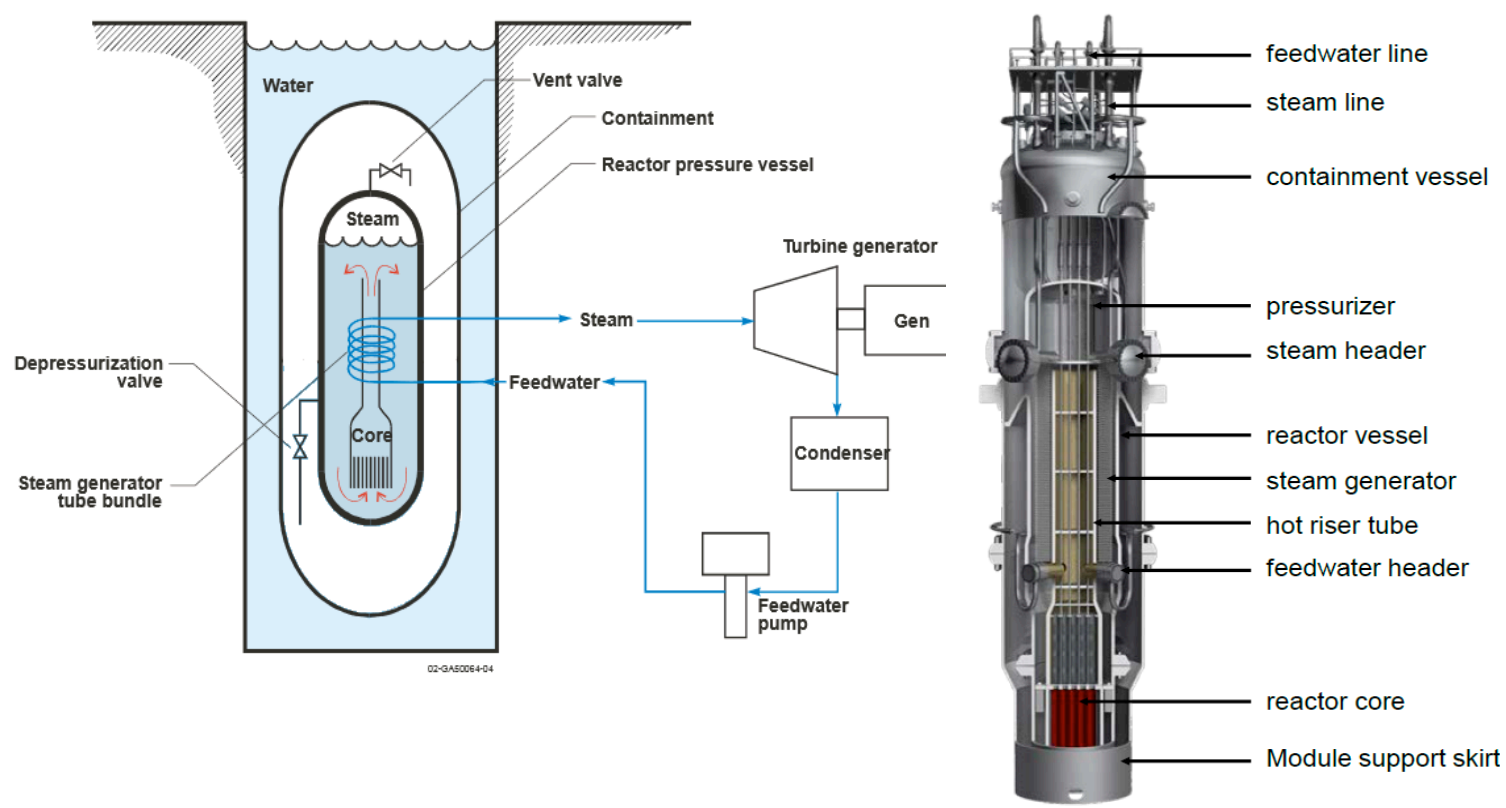

Figure 1. Schematic diagram [22] and 3D view of SMR with naturally circulating primary system[26]

During normal operation, water in reactor primary system is heated by fuel rods in the core to produce a low density fluid that flows upward through the hot-leg riser. On the other side, helical coil steam generators that wrapped around the outside of the riser provide heat sink that cool down the water, causing its density to increase. The density different acting over an elevation results in a buoyancy force that drives the fluid flows around the loop and continuously circulates the coolant.

Tabel 1. General characteristic of SMR with naturally circulating primary system [28, 29]

\begin{tabular}{ll}
\hline Parameter & Content \\
\hline Reaktor type & PWR \\
Thermal Power (MWt) & 160 \\
Electrical output (MWe) & 50 (gross) \\
Steam generator & 2 bundles, helical pipe, vertical dan once through \\
Steam cycle & Rankine - Slightly superheated \\
Fuel bundle & 37 \\
Refueling Intervals & $24-48$ month \\
Primary system pressure (MPa) & 12.8 \\
\hline
\end{tabular}




\section{Reactor Core}

The core consists of 37 fuel assemblies and 16 control rod assemblies. The fuel assembly design is derived from a standard $17 \times 17$ PWR fuel assembly with nominally half the height of standard plant fuel and contains 5 spacer grids. The U-235 enrichment is about 4.95 percent. For selected rod locations, the $\mathrm{UO}_{2}$ in fuel pellet is homogeneously mixed with $\mathrm{Gd}_{2} \mathrm{O}_{3}$ as a burnable absorber.

\section{Steam generators}

The reactor has two once-through helical coil steam generators (SGs). The SGs are fully integrated within the reactor pressure vessel (RPV) and placed in annulus between the upper riser and the RPV shell. Feed water (FW) enters the SGs through the feed plenums, flows upward through the inside of the tubes and is discharged via the steam headers. At the primary side, reactor coolant flows upward through the upper riser, then is turned by the pressurizer baffle plate, and flows down through the helical bundle. The SG is designed to be replaceable and consists of tubes with average length of $30.1 \mathrm{~m}$ and total heat transfer area about $1624.2 \mathrm{~m}^{2}$ [28]. For emergency situation, the feed water system is fortified with passive emergency feed water system that will allow water in the pool to passively enter the helical coil by opening control valves.

\section{RELAP5 MODELING}

To analyze the thermal-hydraulic characteristic and natural circulation flow in SMR with naturally circulating primary system, the reactor system was modeled and then numerical simulation was performed. In this study the computer code used was RELAP5 mod 3.4 which is commonly used for reactor thermal-hydraulics analysis and benchmark [30-32]. In RELAP5, reactor components and hydraulic volumes are represented by generic models that combined into reactor-system configuration. The models used comprise of primary and secondary systems. The primary system included are: 1) reactor core, 2) riser (hot-leg in conventional PWR), 3) shell side of steam generator, 4) down-comer, 5) lower plenum and 6) pressurizer and the secondary system included are: 1) feed-water source, 2) feed-water pump, 3) tube-side of helical steam generator, 4) main steam line and 5) turbine. In addition, the place where the heat is transferred was also modelled, i.e. 1) reactor core 2) steam generator, 3) core baffle and 4) wall between down-comer and bypass channel. The complete nodalisation is shown in Figure 2. 


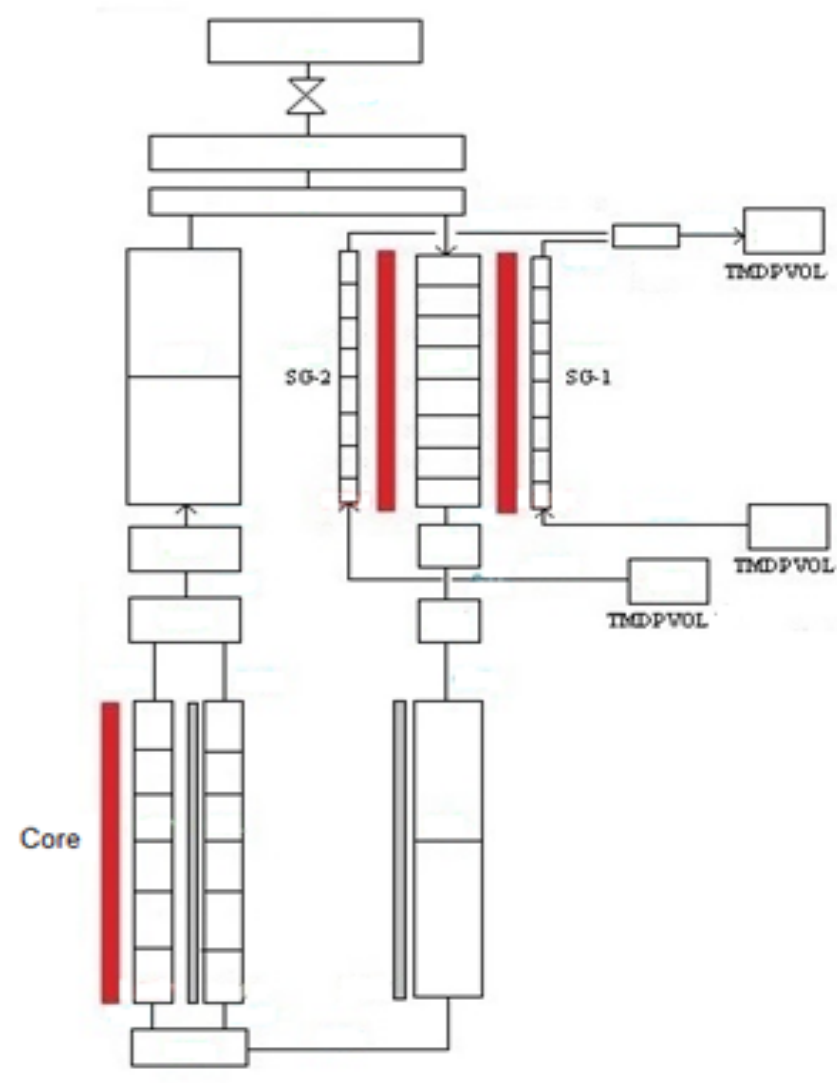

Figure 2. Nodalisation of SMR with naturally circulating primary system in RELAP5

\section{STEADY STATE CALCULATION AND VALIDATION}

The simulation for thermal hydraulic analysis was started with calculation to reach steady state at nominal power. Boundary conditions were set accordingly to application of the reactor for co-generation of electricity and water, i.e. at primary side the core power and pressure were 160 MWt and 12.8 MPa, respectively and at secondary side, each steam generator was fed with $68 \mathrm{~kg} / \mathrm{s}$ of water at $422 \mathrm{~K}\left(149^{\circ} \mathrm{C}\right)$ to produce steam at $3.5 \mathrm{MPa}$ [29]. When steady state was reached, the stable natural circulation of coolant in the primary system was found to be $711 \mathrm{~kg} / \mathrm{s}$, in which the cold leg temperature was about $547.3 \mathrm{~K}$ and the temperature increase in the core is about $41 \mathrm{~K}$. At the secondary side, steam temperature in the main steam line was $575.8 \mathrm{~K}$, that showed a superheated condition (about $60 \mathrm{~K}$ above the saturated value). The summary of steady state calculation result can be seen in the Table 2. For validation purpose, the result is accompanied with the data gathered from the references.

Table 2. Steady state calculation results

\begin{tabular}{lll}
\hline Parameters & Steady state calculation & Reference plant data [29] \\
\hline Reactor Power $(\mathrm{MWt})$ & 160 & 160 \\
RCS Pressure $(\mathrm{MPa})$ & 12.8 & 12.8 \\
Steam flow rate $(\mathrm{kg} / \mathrm{s})$ & 68.0 & $68[27]$ \\
Feed water temperature $(\mathrm{K})$ & 422 & 422 \\
Steam pressure $(\mathrm{MPa})$ & $3.5 \mathrm{MPa}$ & $3.5 \mathrm{MPa}$ \\
Steam temperature $(\mathrm{K})$ & 575.83 & 575 \\
Primary flow rate $(\mathrm{kg} / \mathrm{s})$ & 711.16 & - \\
\hline
\end{tabular}




\section{LOSS OF FEED WATER ACCIDENT}

\section{Scenario and assumption}

The accident scenario investigated was the failure of pump in one of feed water lines. During the accident, the emergency feed water system was presumed to be not functioning due to failure to open control valves. As consequence, the reactor power tripped following the signal from low flow rate in the feed line. The disabled line was assumed to completely stop supplying water within 5 second since the start of initiating event which caused infirmity of the pump. In this simulation, the reactor was assumed to be running at its rated full power before the accident.

\section{Calculation result and discussion}

Calculation result for the above scenario is shown in the Figure 3 and Figure 4 . Figure 3 displays condition in secondary side and Figure 4 exhibits situation in primary side of reactor system during the transient of loss of feed water accident. The figures show that initially feed water flow rate in each of the two SGs is $34 \mathrm{~kg} / \mathrm{s}$ and the total heat transferred through SGs is $160 \mathrm{MW}$ (each SG transfers about $80 \mathrm{MW}$ ). At that juncture one of FW pumps stopped flowing water within 5 seconds (see SG-1flow rate chart). Two situations that relate one another occur following the initiating event.

First situation: At early stage of the accident the halt of feed water in one FW line caused heat transfer in the SG-1 decreases for a short period as no more cold water enters the lower part of helical tubes (see Figure 3). Afterward the remaining water inside the tubes becomes saturated which make the heat transfer inside the tube very effective. This is shown in the chart where the heat transfer value increases again at $\mathrm{t}=5$ seconds. However, this situation does not stay long. After sometime ( $\mathrm{t}=8$ seconds), no more water is in the tubes so that the heat transfer drops drastically. In the SG-2, the transient occurs in SG-1 during early phase of the accident causes the heat transfer in SG-2 fluctuated. When SG-1 stops taking out the heat, the SG-2 took more heat from the primary system for compensating the heat balance. However, after that the heat transferred is decreasing because the reactor power has dropped due to trip signal. Meanwhile, the condition of steam produced in the SGs also dynamically changes. In general, the steam gradually descends from superheated to saturated conditions in proportion with the heat transferred in SGs. Within 90 seconds its temperature has become saturated and keeps staying at this condition for the rest of simulation. The steam condition is very important for the safety of turbine. A helical SG is not equipped with steam separator and dryer so it must produce bulk of dry steam before sending it into turbine. Otherwise the steam could damage the turbine blades. This fact suggests that the turbine bypass valve must have been opened earlier (less than 90 seconds) to redirect the steam into condenser in order to protect the turbine.

Overall, as consequence to the halt of single FW line, the heat transfer to secondary side is reduced significantly. This reduction apparently would cause an increase in the temperature of primary system afterwards. 


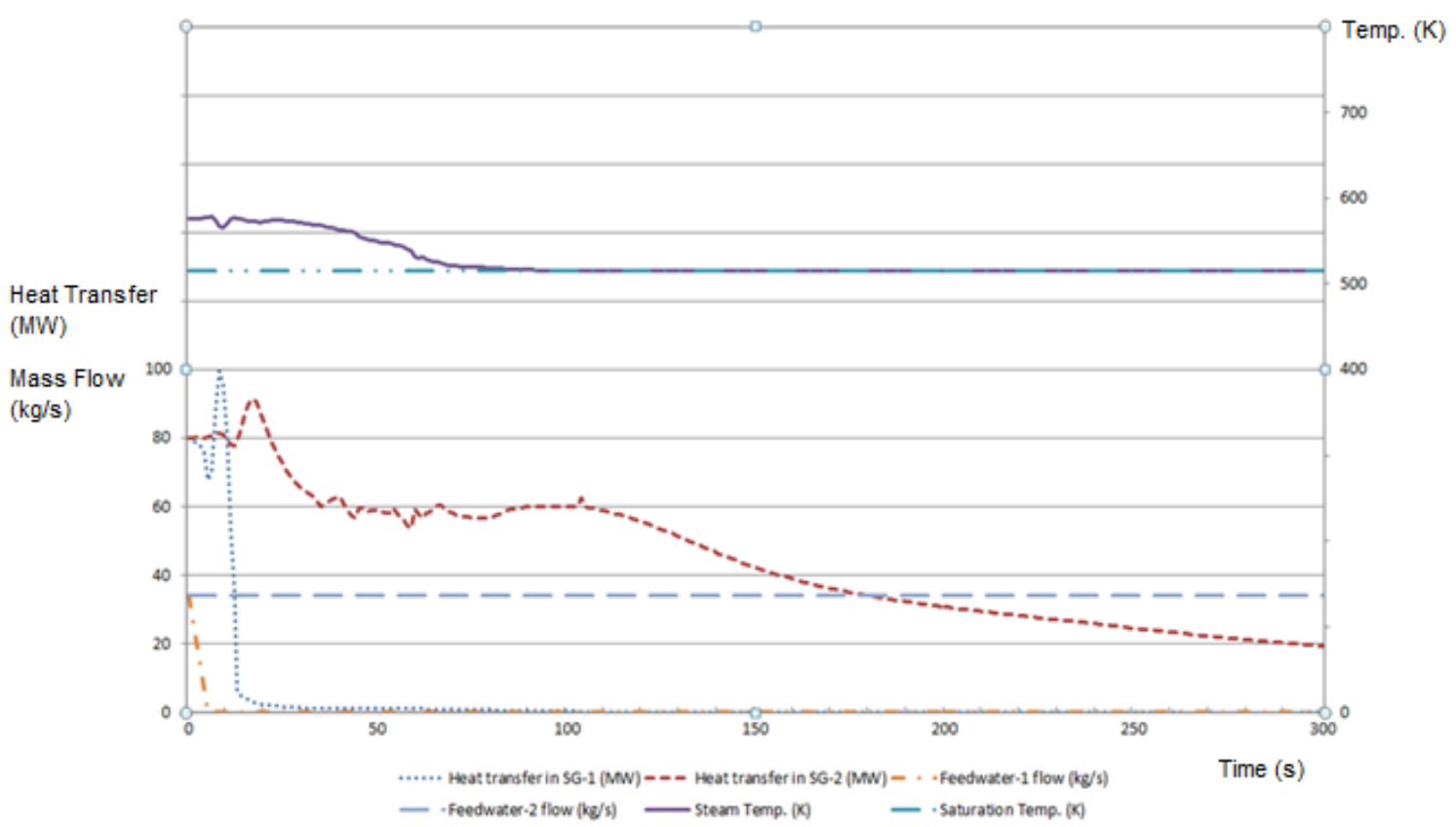

Figure 3. The dynamic in secondary side of reactor during loss of feed water accident.

Second situation: The trip signal from low flow in feed water lines instigates the reactor power significantly dropped (see Figure 4). As a result the coolant temperature leaving the core falls down due to energy given to it plunged. With the power decreases and only one SG is available to take out the heat from primary system, the energy passed to secondary side considerably decreases. Subsequently, the temperature different between hot leg (the riser) and cold leg (the down comer) reduces and the differential coolant density between the two sections also gets lesser. Recalling that driving force for circulating the coolant is the density different, hence the coolant flow rate decreases also.

The combination of power change in the core and heat removal in the SGs causes fluctuation in the primary system flow. The mass flow drops soon after reactor trip. Then, at $\mathrm{t}=\sim 46$ seconds flow reduction reaches the lowest point of $\sim 263 \mathrm{~kg} / \mathrm{s}$ and afterwards the flow bounces back to increase. However at $\mathrm{t}=\sim 105$ seconds the flow in the primary system decreases again. Analyzing such flow pattern, it can be seen that the condition at $t=46$ seconds is a critical moment as this point is the slowest flow rate during the first few seconds after the initiating accident. At this time, clarification whether safety limits have been surpassed should be done. A further check shows that the fuel centerline and the coolant temperatures are $\sim 565 \mathrm{~K}$ and $\sim 554 \mathrm{~K}$, respectively. This indicates that the fuel center temperature is far below its design limit and the coolant temperature is much lower than its saturation.

In addition, subsequent condition shows that all parameters are decreasing into a stable condition. At the fifth minutes of transient the system pressure reduces into $\sim 6.13 \mathrm{MPa}$. Besides, the hot leg and cold leg temperature are $521 \mathrm{~K}$ and $516 \mathrm{~K}$, respectively. The transient trend is following the residual heat removal which gets lower along the elapsed time. These facts show that during loss of feed water accident, the SMR with naturally circulating primary system remains in safe condition. 


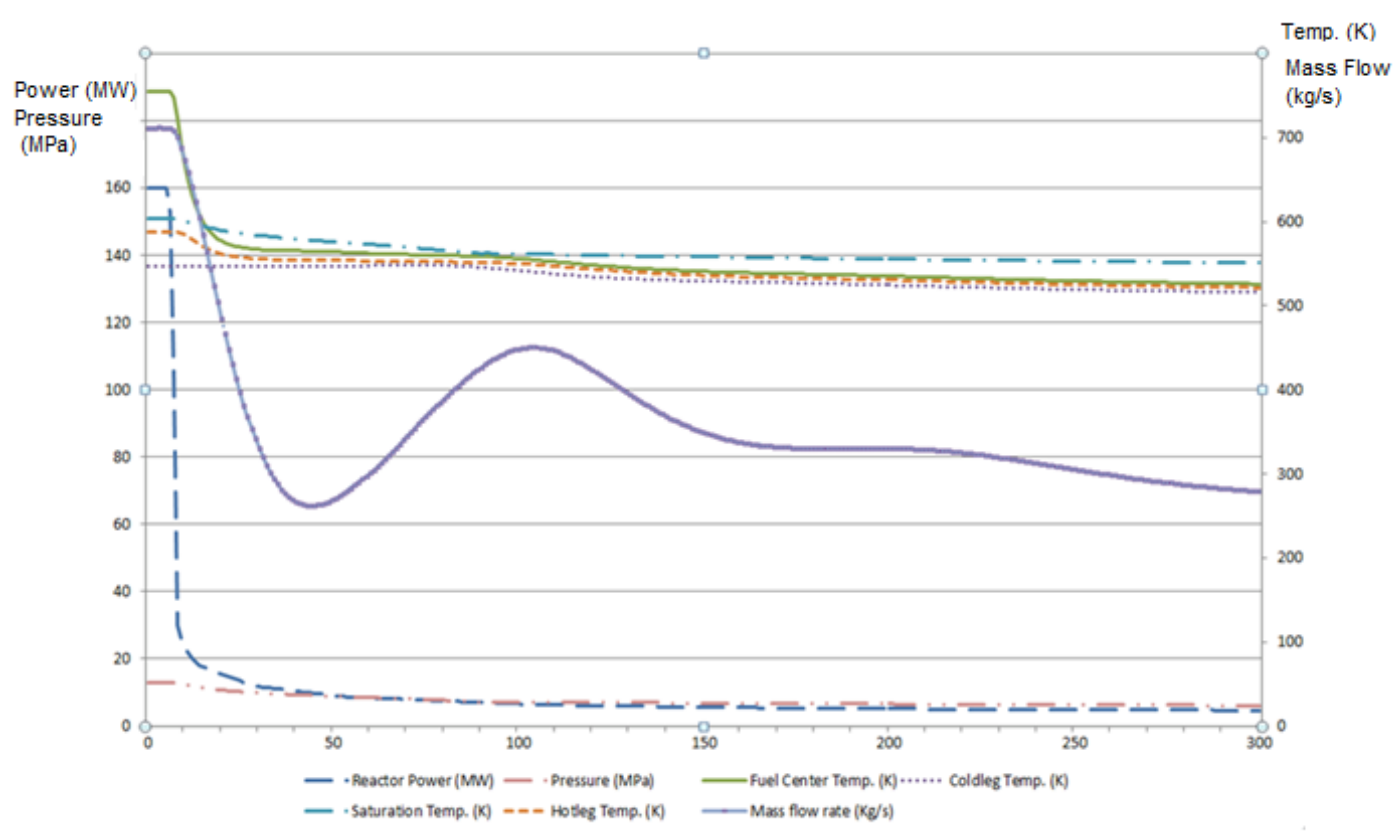

Figure 4. The dynamic in primary side of reactor during loss of feed water accident.

\section{CONCLUSION}

Numerical simulation on LoFW accident occurring in SMR with naturally circulating primary system has been conducted. Calculation result shows that after the initiating event the steam gradually descends from superheated to saturated conditions in proportion with the heat transferred in SGs. Within 90 seconds the steam becomes saturated and remains at this condition for the rest of simulation time. This fact suggests that the turbine bypass valves must have been opened beforehand to redirect the steam into condenser in order to protect the turbine blades.

In the primary system, low flow condition in FW line initiates reactor trip which brings the primary flow drops from $714 \mathrm{~kg} / \mathrm{s}$ to $263 \mathrm{~kg} / \mathrm{s}$ within 46 seconds. After that, the flow increases but then drops again at $\mathrm{t}=105$ seconds. During the fluctuation it could be seen that fuel centerline temperature is still far below its design limit. Besides, the coolant temperature also remains under its saturation temperature. In addition, subsequent condition shows that all parameters are decreasing into stable conditions. From this fact, it could be concluded that during LoFW accident, the SMR with naturally circulating primary system remains in safe condition.

\section{ACKNOWLEDGEMENT}

This work was supported by the national project fund (DIPA) and the author would like to acknowledge the National Atomic Energy Agency of Indonesia (BATAN) for providing facilities to perform the calculation.

\section{REFERENCES}

1. Hidayatullah, H., S. Susyadi, and M.H. Subki, Design and technology development for small modular reactors-Safety expectations, prospects and impediments of their deployment. Progress in Nuclear Energy 2015; 79:127-135.

2. Rijanti, R.A.P. and S.M. Lumbanraja, Studi Prospek PLTN Daya Kecil NUSCALE di Indonesia. Jurnal Pengembangan Energi Nuklir 2012; 14(1):57-64. 
3. Ariyanto, S., Sistem mPower dan Prospek Pemanfaatannya di Indonesia. Jurnal Pengembangan Energi Nuklir 2012; 14(2):136-143.

4. Lumbanraja, S.M. and Y. Yuliastuti, Kajian Pemanfaatan PLTN SMART Untuk Kawasan Barelang. Jurnal Pengembangan Energi Nuklir 2006; 8(2):13-21.

5. Lumbanraja, S.M., A.P. Rijanti, and I. Bastori, Kajian Tekno-Ekonomi Reaktor Inovatif IRIS-350. Jurnal Pengembangan Energi Nuklir 2005; 7(1):29-42.

6. Lumbanraja, S.M., Kajian Implementasi FLEXBLUE di Indonesia. Jurnal Pengembangan Energi Nuklir 2014; 16(2):107-117.

7. Black, G., et al., Carbon free energy development and the role of small modular reactors: A review and decision framework for deployment in developing countries. Renewable and Sustainable Energy Reviews 2015; 43:83-94.

8. Vujić, J., et al., Small modular reactors: Simpler, safer, cheaper? Energy 2012; 45(1):288295.

9. Rowinski, M.K., T.J. White, and J. Zhao, Small and medium sized reactors (SMR): A review of technology. Renewable and Sustainable Energy Reviews 2015; 44:643-656.

10. Liu, Z. and J. Fan, Technology readiness assessment of small modular reactor (SMR) designs. Progress in Nuclear Energy 2014; 70:20-28.

11. Prasad, S., et al., Nonproliferation improvements and challenges presented by small modular reactors. Progress in Nuclear Energy 2015; 80:102-109.

12. Laina, M.-K. and M.H. Subki, Status, Generic Technical Issues and Prospect of Small and Medium-Sized Reactors Development and Deployment. Fusion Science and Technology 2012; 61(1T):178-185.

13. Liao, J., et al. Preliminary LOCA analysis of the westinghouse small modular reactor using the WCOBRA/TRAC-TF2 thermal-hydraulics code. in ICAPP. 2012. Chicago, Illinois, USA: American Nuclear Society.

14. Halfinger, J.A. and M.D. Haggerty, The B\&W mPower ${ }^{\mathrm{TM}}$ Scalable, Practical Nuclear Reactor Design. Nuclear technology 2012; 178(2):164-169.

15. Reyes Jr, J.N., NuScale Plant Safety in Response to Extreme Events. Nuclear Technology 2012; 178(2):153-163.

16. Kim, K.K., et al., SMART: the first licensed advanced integral reactor. Journal of Energy and Power Engineering 2014; 8:94-102.

17. Zverev, D., et al., RITM-200: new-generation reactor for a new nuclear icebreaker. Atomic Energy 2013; 113(6):404-409.

18. Zhu, D., et al., Evaluation of in-vessel corium retention margin for small modular reactor ACP100. Annals of Nuclear Energy 2016; 94:684-690.

19. Magan, H.B., et al., CAREM project status. Science and Technology of Nuclear Installations, 2011. 2011(Article ID 140373): p. 6

20. Bánáti, J., C. Demazière, and M. Stålek, Analysis of a loss of normal feedwater transient at the Ringhals-3 NPP using RELAP5/Mod. 3.3, 2010, US Nuclear Regulatory Commission.

21. Ekariansyah, A.S., et al., Verifikasi Kecelakaan Hilangnya Aliran Air Umpan Pada Reaktor Daya PWR Maju. Tri Dasa Mega 2015; 14(2):76-90.

22. Reyes, J.N., et al., Testing of the multi-application small light water reactor (MASLWR) passive safety systems. Nuclear Engineering and Design 2007; 237(18):1999-2005.

23. Chung, Y., et al., Development and assessment of system analysis code, TASS/SMR for integral reactor, SMART. Nuclear Engineering and Design 2012; 244:52-60.

24. Del Nevo, A., D. Rozzia, and P. Agostini. Investigation of RELAP5 code capability in predicting phenomena in a SMR system. in the 21st Int. Conf. Nuclear Energy for New Europe. 2012. Ljubljana, Slovenia.

25. Park, J., Simulation of loss of feedwater transient of MASLWR test facility by MARSKS code, in Transactions of the Korean Nuclear Society Spring Meeting 2013: Gwangju, Korea.

26. Ingersoll, D.T., et al. Can Nuclear Power and Renewables be Friends? . in ICAPP. 2015. Nice, France. 
27. Ingersoll, D.T., et al. NuScale Energy Supply for Oil Recovery and Refining Applications. in ICAPP. 2014. Charlotte, North Carolina, USA American Nuclear Society.

28. Jose N. Reyes, J., Introduction and Overview of NuScale Design, in U.S. NRC PreApplication Meeting 2009, NuScale Power: Rockville, MD.

29. Ingersoll, D.T., et al., NuScale small modular reactor for Co-generation of electricity and water. Desalination 2014; 340:84-93.

30. Skrzypek, M. and R. Laskowski, Thermal-hydraulic calculations for a fuel assembly in a European Pressurized Reactor using the RELAP5 code. Nukleonika 2015; 60(3):537-544.

31. Abdelrazek, I., et al., Benchmarking RSG-GAS reactor thermal hydraulic data using RELAP5 code. Annals of Nuclear Energy 2014; 70:36-43.

32. Mangal, A., V. Jain, and A. Nayak, Capability of the RELAP5 code to simulate natural circulation behavior in test facilities. Progress in Nuclear Energy 2012; 61:1-16. 